\title{
The Vertical Distribution of Marine Macroplankton. VI. Further Observations on Diurnal Changes.
}

\author{
By \\ F. S. Russell, D.S.C., B.A. \\ Assistant Naturalist at the Plymouth Laboratory.
}

With 7 Figures in the Text.

Is 1925 observations were carried out on two consecutive nights, June 17-18th and 18-19th, to study the diurnal changes occurring in the vertical distribution of certain marine plankton animals. Serial hauls were made with the stramin ring-trawl in the manner described in a previous publication (1). The series were so timed that they were made approximately in daylight, dusk, darkness, dawn and daylight on the two days in question. The actual details of the collecting, together with the fishing depths shown by the Admiralty depth recorder, are to be found in a previous paper on the behaviour of young fishes on the same occasion (2).

\section{General Results.}

In considering the general results as shown by the collections it is necessary to bear in mind that each haul in a series is consecutive, i.e. that the six depths were not fished simultaneously. Thus, for instance, in the first series the observations extended over a period of nearly two hours, so that, while the deepest haul was taken at 2.35 p.m., the surface haul was not taken until 4.19 p.m. During so long a period there is sufficient time for the vertical distribution of the plankton to become considerably altered. However, during full daylight and in darkness, when the light conditions which appear to control the behaviour of the animals to a large extent are more or less constant, or at any rate only changing slowly, it seems most probable that little alteration will occur in the vertical distribution and that the results shown in the diagrams will illustrate the actual distribution of the animal during that period within small limits. But it may be quite otherwise at dusk and at dawn, when the light is decreasing or increasing in strength very rapidly.

This possibility should be remembered when the results of the collections are examined. To emphasize this point an illustration is here given. In Fig. 3 (p. 88) the distribution of Tomopteris helgolandica at dusk NeW series. - Vol. XV. No. 1. FEBrUARY, 1928. 
(7.27-9.23 p.m.) on the first night would appear to have been fairly uniform from the surface downwards, but the numbers of individuals at each depth were small. But it must be realised that when the surface haul was being taken at 9.13 p.m. the distribution that existed at 7.27 p.m., when the bottom haul was taken, had probably considerably changed. It is very possible that, by the time this surface haul was taken, the deeper levels had already received a marked addition to their Tomopteris population by the rising of individuals from near the bottom. In the drawing of the diagrams in this paper this time factor has been ignored and Fig. 1 shows how the distribution should have been represented in the case of Tomopteris at dusk. In this figure the diagram B represents the distribution as it has been given in Fig. 3 (p. 88), whereas

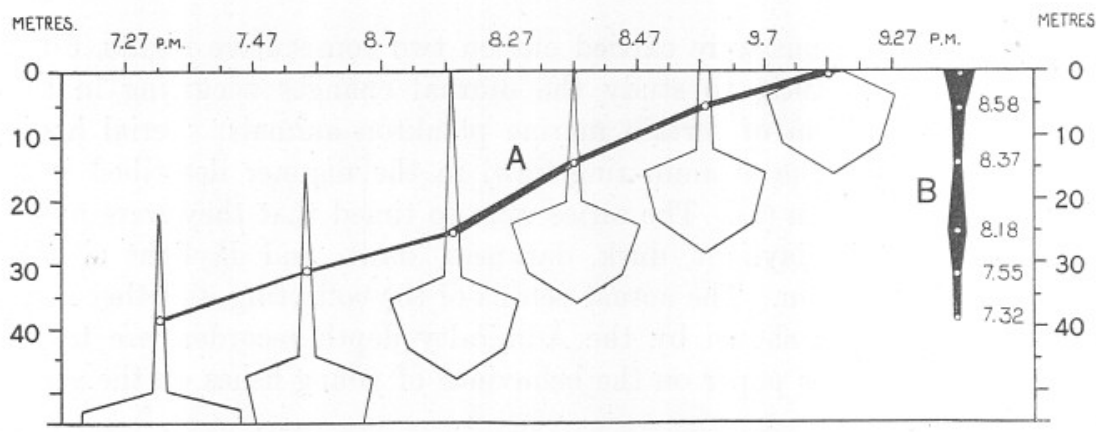

FIG. 1.-Illustrating how the diagram B for the dusk distribution of Tomopteris helgolandica may be misleading. Diagram A shows the same distribution with the time factor introduced. Hypothetical distributions for Tomopteris at the various times at which hauls were made are drawn in outline.

A shows the same diagram with the time factor introduced. At the same time, by means of unblackened outline diagrams, is shown hypothetically what the actual distribution of Tomopteris may quite well have been at the times that the hauls at the various depths were taken. Thus, while being very close to the bottom at 7.27 p.m., they may have been well on their way towards the surface by 9.13 p.m. when the surface haul was begun. Arguing on the theory that has already been outlined for the behaviour of plankton animals (4, p. 237), it is unlikely that at dusk only a few Tomopteris were present at all layers as indicated in Fig. 3, and it may well be that the suggested distribution shown in Fig. 1 comes nearer the truth. In the case of the dusk diagram on the first night for Turris pileata (Fig. 2, p. 84), however, if the net has fished each time below the mass of upwardly migrating medusæ until the surface layers were reached, a true idea of the actual distribution at about 9 p.m. is possibly given. (It should be quite possible to test the above suggestion by taking the series of hauls on a future occasion in the reversed 
order, viz. from the surface downwards. Under such conditions it is easy to see that the dusk distribution for Tomopteris would work out as that suggested for 8.37 p.m. in Fig. 1, if the hypothetical behaviour there outlined is anywhere near correct.) This suggestion is also borne out by an examination of the behaviour of Tomopteris on the night of July 15-16th, 1924 (1, p. 785), when the hauls were taken from below upwards as on the present occasion. In Fig. 3 of that publication it can be seen that in the daylight the Tomopteris were already well up in the water, and the resulting diagram for the dusk distribution can be explained in the manner shown here in Fig. 1.

Turning now to the results obtained in this series of collections, it is not the intention in these pages to enter into discussion on the various types of behaviour shown, nor to undertake comparisons between these results and those obtained on July 15-16th, 1924. There are certain very obvious differences between the two, some of which, e.g. Sagitta and Tomopteris, can be explained by the different behaviour of these animals in the daylight at the different seasons that the two collections were made (3). The actual details of the behaviour of the various species are given in the following pages, and since another series has already been collected in 1926, and worked up, opportunity will be afforded in a forthcoming publication to compare the results of all four nights.

Full details of the numbers of the different species caught at the different depths are given in Table I on page 100 .

Throughout the paper the expressions "daylight," "dusk," "dark," and "dawn" have been used to cover the various periods during which the series were taken. It must be realised that these are purely arbitrary expressions and the actual times are given in the many diagrams and in Table I (p. 100).

The fact that on so many occasions the behaviour of a species on the first night is almost exactly repeated on the second night gives reason for supposing that the method of collecting is efficient and that the numbers of animals caught in the different hauls are strictly comparable.

The catches were sampled in the same way as previously, the larger animals $(3$, p. 563) being picked out completely: in the smaller catches one-fifth of the whole was counted.

\section{COELENTERATA.}

\section{ANTHOMEDUS}

Steenstrupia RUBRA Forbes.

In the daytime there were no specimens of this medusa taken from above 20 metres. On the first night, June 17-18th, the numbers were 

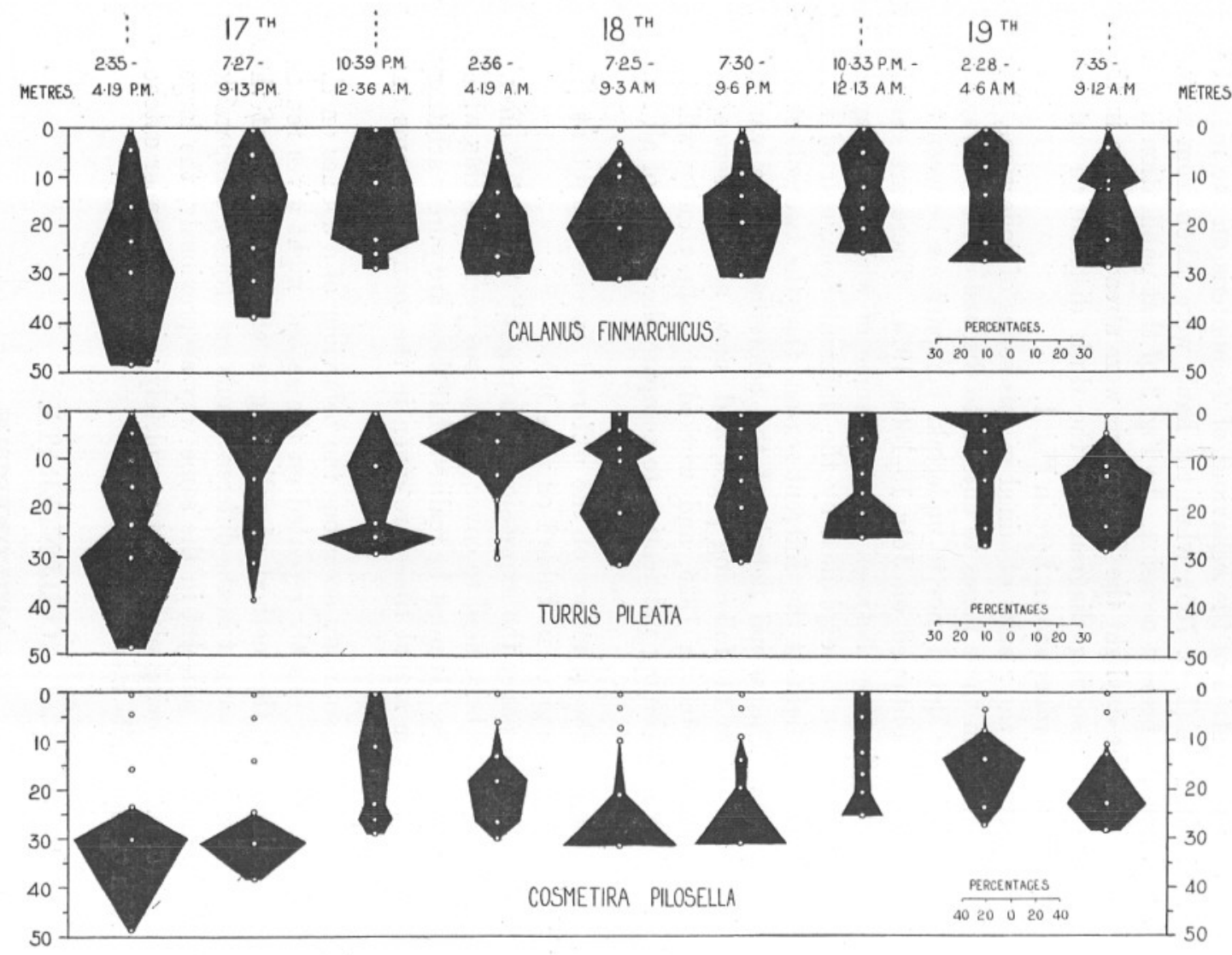

FIG. 2.-The percentage vertical distribution of Calanus finmarchicus, Turris pileata, and Cosmetira pilosella, at the times shown, on June 17-18-19th, 1925. The white spots and black circles indicate the average depths at which hauls were taken. 
rather low, only 2 being caught on the surface and 10 and 12 at 26 and $29 \mathrm{~m}$. respectively. However, on the second night the numbers were sufficient to show that in the dark there had been a decided movement into the layers above $20 \mathrm{~m}$., 52 being taken at $12 \cdot 2 \mathrm{~m}$. and 33 at $16 \cdot 6 \mathrm{~m}$. Only one was caught at the surface. At dawn on both days the layers above 20 metres had once more been vacated, but on June 18th there were still 54 at $26 \cdot 8 \mathrm{~m}$.

\section{TurRis pileata (Forskal).}

In the daytime on June 17th and 18th the numbers of Turris in the collections were too low to give a true picture of the vertical distribution. On June 19th, however, they were more numerous, and it is probable that this (Fig. 2) can be regarded as their normal daylight distribution. On both nights - but more markedly on the first-there seems to have been an active migration to the surface itself at dusk, followed by a downward movement at night in the dark and a further upward migration at. dawn.

\section{Bougatnvillea sp.}

Although the numbers of Bougainvillea, as shown in Table I, are very small there seems undoubted evidence that they moved into the upper layers at night. None were taken at any depth in the three daylight series, but by dusk on both days they were beginning to appear in the deeper hauls.

In the dark on the first night they were present at the surface itself, and by dawn they were still everywhere between $6 \mathrm{~m}$. and $30 \mathrm{~m}$. On the second night only few were taken, although they were numerous again at dawn.

Slabberia halterata Forbes and Stomatoca dinema L. Agassiz only occurred in one or two collections and then generally singly.

\section{LEPTOIMEDUSЖ.}

\section{OBELIa SP.}

The catches of Obelia were very small, and appear to indicate little coordinated movement. On the two occasions when they were numerous, dusk on June 18th and daylight on June 19th, their distribution was much the same, except that at dusk they were abundant on the surface itself and in the daylight there were few in the upper five metres. 


\section{Phialidium sp.}

There appear to be definite indications of an upward movement on the part of these medusæ at night (Fig. 4). They were almost completely absent in the daylight on June 17th, at dusk they were most abundant below $25 \mathrm{~m}$., and in the dark they were evenly distributed from the surface downwards. At dawn on June 18th the majority were taken below $15 \mathrm{~m}$. In the daylight, however, they appear to have become evenly distributed again from $3 \mathrm{~m}$. downwards, but their numbers are somewhat reduced. A rather similar behaviour was shown on the second night, only, in the dark, the majority were caught between 10 and $20 \mathrm{~m}$.

\section{Cosmetira pILOSElla Hartlaub.}

None of these medusæ were captured from above $20 \mathrm{~m}$. in the daylight on June 17th, and the majority occurred at $30 \mathrm{~m}$., or perhaps deeper, there being rather a deep layer between the two bottom hauls. At dusk the distribution was still much the same, most being at $30 \mathrm{~m}$. In the dark Cosmetira was evenly distributed from the surface down to $30 \mathrm{~m}$. At dawn there had been a downward movement and the majority lay between 15 and $30 \mathrm{~m}$. This movement was continued in the daylight so that most were taken at $30 \mathrm{~m}$., and possibly they may have lain even deeper. On the following night the behaviour exhibited by Cosmetira was almost exactly the same (Fig. 2).

\section{Saphenta gracilis (Forbes and Goodsir.).}

No Saphenia were taken in the daytime on June 17th at any depth. At dusk they were beginning to appear in the deeper hauls, 37 being caught at $31 \cdot 3 \mathrm{~m}$. In the dark they were distributed from the surface downwards. They had almost completely disappeared by dawn and in the daylight on the following day. On the next night they once more appeared from the surface downwards, although most of them were caught below $15 \mathrm{~m}$. The numbers on all occasions were rather low, and the impression gained is that in its diurnal behaviour Saphenia resembled Cosmetira, except that in the daytime it went possibly deeper.

Of the Scyphomedusæ, Cyanea capillata Eschscholtz and Aurelia aurita Lamarck, too few were taken to indicate what the changes in their vertical distribution may have been, as was also the case with the Ctenophore, Pleurobrachia pileus Fab., and the Zoantharians. Peachia sp. larvæ and Arachnactis Bournei Fowl. 


\section{ANNELIDA.}

\section{POLYCHÆTA.}

\section{TOMOPTERIS HELGOLANDICA Greef.}

In the daytime on June 17th Tomopteris was extremely rare above $50 \mathrm{~m}$., and the majority were probably very close to the bottom. The dusk diagram (Fig. 3) exhibits a slight upward movement, but, as explained previously (p. 81), this may be misleading, only the forerunners of the main upward moving mass being sampled at each depth. In the dark there was a filling up of the layers from the surface downwards, the majority being at about $10 \mathrm{~m}$. At dawn on June 18th the distribution was somewhat similar to that in the dark, except that most were taken at $20 \mathrm{~m}$. and the surface itself was vacated. By daylight they had presumably once more returned to very near the bottom.

The following night, June 18th to 19th, this behaviour was almost exactly repeated, except that in the dark there were fewer at the actual surface itself.

\section{Larva of Pecilochatus serpens Allen.}

Although these polychæte larvæ were very rare in the catches throughout the first twenty-four hours, on the second night there were definite indications that they had moved into the upper layers, although the numbers taken were still very low.

\section{CHÆTOGNATHA.}

Sagitta bipunctata Quoi and Gaimard.

As was the case with Tomopteris, there are indications that the Sagitta were living very close to the bottom in the daytime. By dark their numbers were enormously increased in the layers above $30 \mathrm{~m}$., and the Sagitta were very abundant at the surface itself (Fig. 3). They had almost completely disappeared again by dawn. This behaviour was repeated in exactly the same manner on the two nights, except that there were fewer at the surface on the second night than on the first. That the Sagitta may have been lying very close to the bottom in the daylight on these occasions is borne out by experiments carried out this year (1927). In a net specially constructed to sample the layers a few inches above the bottom there have on occasion been extremely large catches of Sagitta made (see 5, p. 108 of this Journal). 

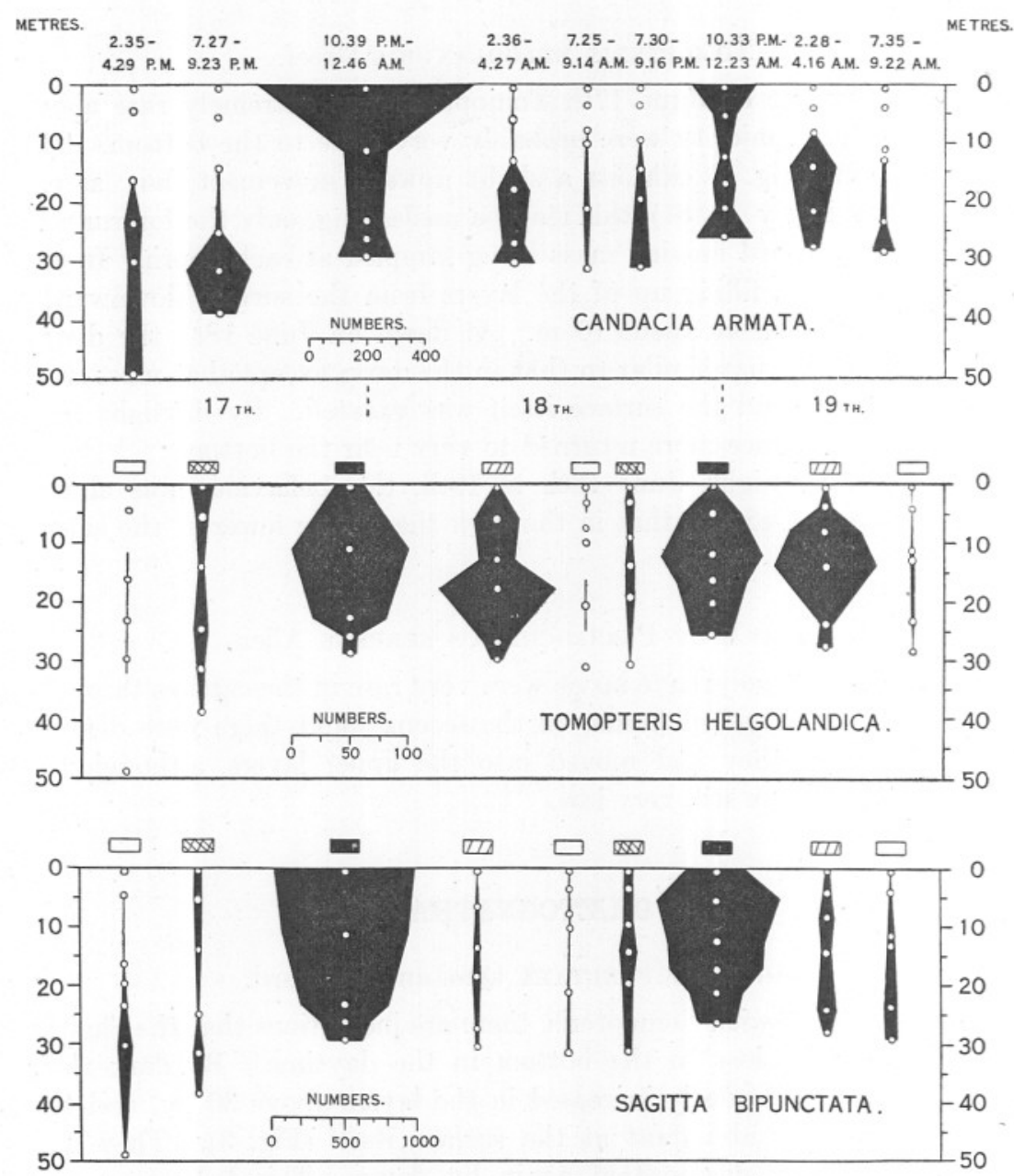

FIG. 3.-The vertical distribution of Candacia armata, Tomopteris helgolandica, and Sagitta bipunctata, at the times shown, on June 17-18-19th, 1925. The plain, cross-hatched, black, and shaded rectangles represent "daylight," "dusk," "dark," and " dawn " respectively. The white spots and black circles indicate the average depths at which hauls were taken. 


\section{CRUSTACEA.}

\section{COPEPODA.}

\section{Calanus finmarchicus (Gunner).}

In the daylight on June 17th the majority of this copepod were taken at $30 \mathrm{~m}$. (Fig. 2). By dusk there had been a marked upward movement. in the water, the greatest catch being at $15 \mathrm{~m}$. In the dark they were mostly distributed between the surface and $25 \mathrm{~m}$. At dawn on June 18th they had left the surface and the majority lay between 15 and $30 \mathrm{~m}$. and perhaps deeper; a somewhat similar distribution was shown in daylight, but the actual surface layers down to $5 \mathrm{~m}$. were almost completely emptied. At dusk on June 18th there seems to have been little change, except that there were more in the layers between the surface and $5 \mathrm{~m}$. In the dark they were evenly distributed from $5 \mathrm{~m}$. downwards with fair numbers at the surface itself. At dawn the distribution was still very similar, but in the daylight the surface layers were vacated. It is evident that the movements as indicated by these collections were not as marked on the second night as on the first.

\section{Candacta armata (Boeck.).}

It is probable that in the daytime these copepods were living very close to the bottom, none being taken above $20 \mathrm{~m}$. and only a few in the hauls below this depth (Fig. 3). At dusk on June 17th the majority were caught between 30 and $35 \mathrm{~m}$. In the dark there was a great massing in the surface layers, while considerable numbers were present down to $30 \mathrm{~m}$. By dawn on June 18th the layers between the surface and $10 \mathrm{~m}$. had been vacated and only a few Candacia were taken between 15 and $30 \mathrm{~m}$. ; by daylight it would appear that they had all moved down below $30 \mathrm{~m}$., the lowest depth sampled. The behaviour on the following night, June 18-19th, was almost exactly similar, the numbers at the surface in the dark being, however, not so great.

Of the remaining copepods, Anomalocera Patersoni Templt. were too few and unevenly distributed to give any indication of their behaviour; Metridia lucens Boeck appeared at any rate in small numbers in the dark on the first night, and in still smaller numbers on the second night, while it was almost completely absent in the daylight; Caligus rapax Milne Edwardes was only taken in small numbers and showed a very irregular distribution. 

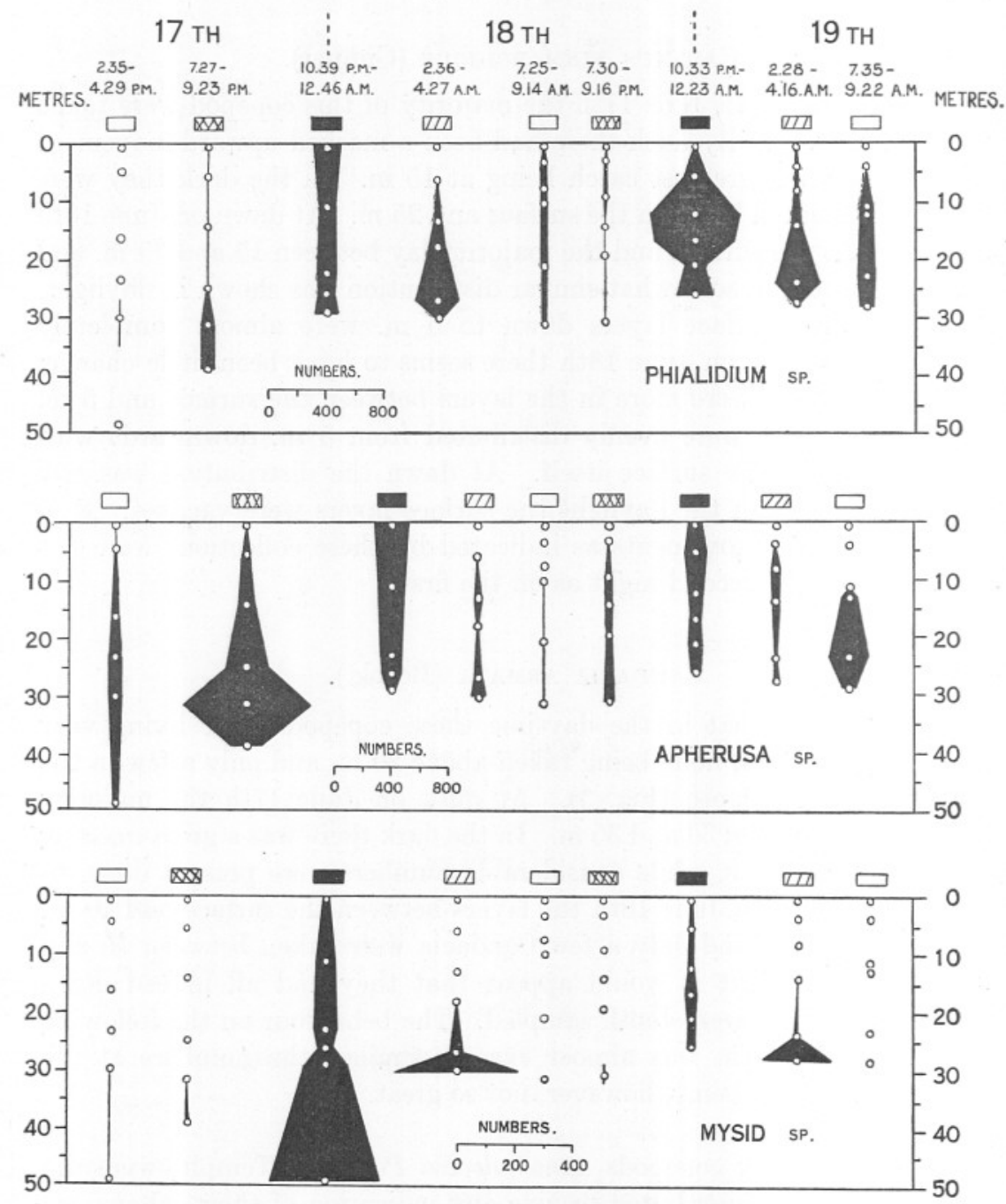

FI $I_{G .}$ 4.-The vertical distribution of Phialidium sp., Apherusa sp., and Mysid spp., at the times shown, on June 17-18-19th, 1925. "The plain, eross-hatched, black, and shaded rectangles represent " daylight," " dusk," " dark," and " dawn " respectively. The white spots and black circles indicate the average depths at which hauls were taken. 


\section{MYSIDACEA.}

Mrsid spp.

The mysids, consisting mostly of the species Leptomysis gracilis (G. 0 . Sars), with a few Schistomysis sp., Dasymysis sp., and Haplostylus Normanni G. 0. Sars, were evidently living in the layers adjacent to the bottom in the daytime, and at dusk they were still absent in the upper layers down to $30 \mathrm{~m}$. (Fig. 4). At night on June 17-18th the layers between the bottom and $30 \mathrm{~m}$. had been greatly filled up. (The mysids, such as could be found, were washed out from the sand that filled the bucket when the net struck bottom during the dark haul.) At the same time there were a few mysids present in the layers between $30 \mathrm{~m}$. and the surface itself. By dawn on June 18th the surface layers down to $25 \mathrm{~m}$. had been completely vacated, but there were still many present at $30 \mathrm{~m}$. In the daylight on June 18th none were caught. This behaviour was repeated on the following night. In the dark series, however, the net was not fished deep enough to sample the layers below $30 \mathrm{~m}$., where the mysids were probably most abundant.

\section{Anchialus agrLIs G. O. Sars.}

This mysid was entirely absent at all depths sampled in the daytime and at dusk on both days. In the dark on both nights they were taken in small numbers at all depths from $5 \mathrm{~m}$. downwards, and on the first night three were taken at the surface itself. At dawn on both days a few were still taken below $20 \mathrm{~m}$.

\section{EUPHAUSIACEA.}

\section{Nyctiphanes Couchir (Bell).}

These euphausiids, while being taken only singly in the deeper layers in the daytime, appeared in small numbers at all depths in the dark on the two nights.

\section{CUIMACEA.}

Cumaceans, Diastylis sp. and others, appeared in the collections only in the dark (except at dawn on June 19th, when two were caught at $27.5 \mathrm{~m}$.), when they were present at almost all depths sampled.

\section{AIMPHIPODA.}

Apherusa spp.

While these amphipods were present in the daytime on June 17th in small numbers from $5 \mathrm{~m}$. downwards, there was a very great increase in 

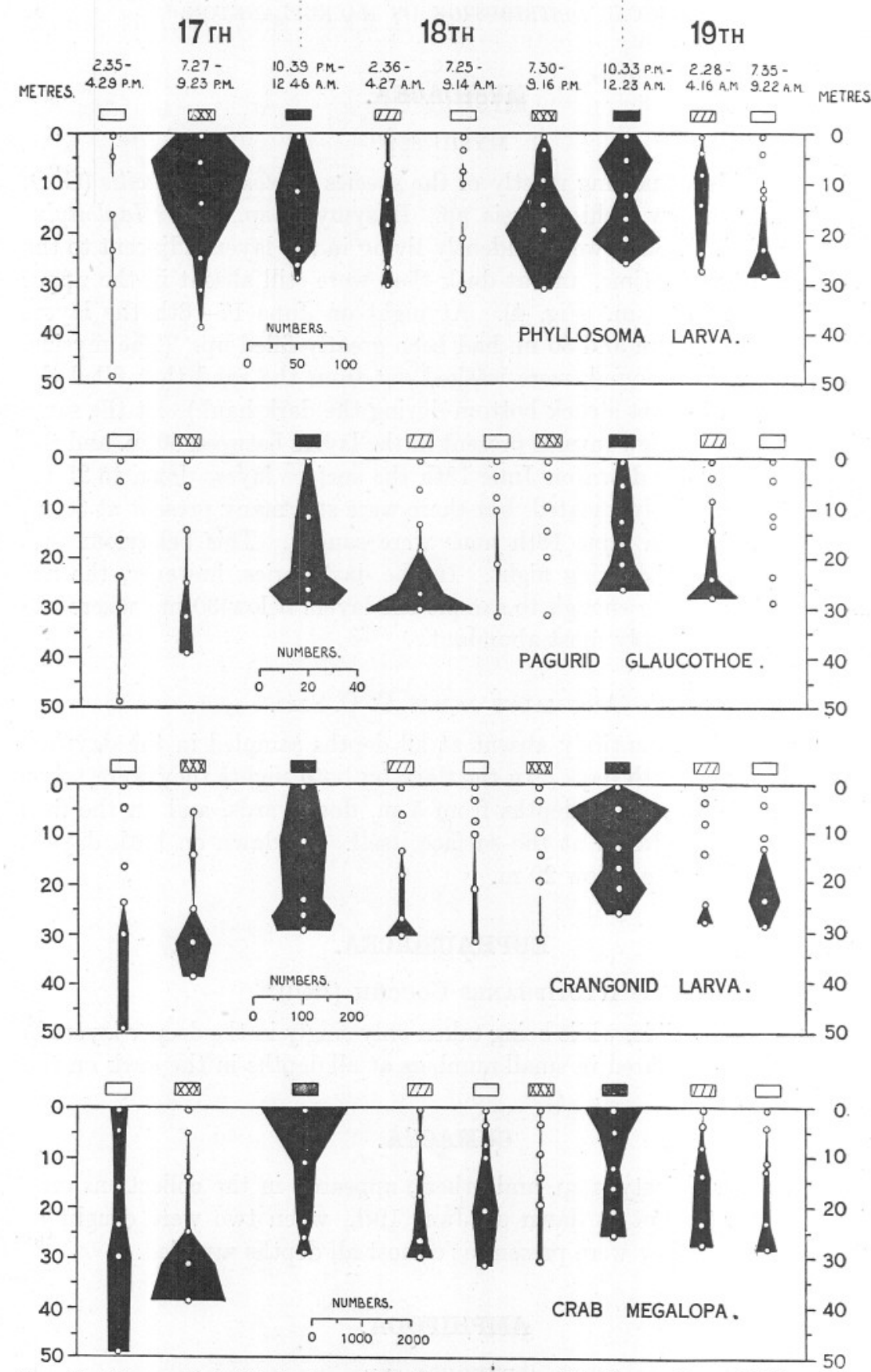

FIG. 5.-The vertical distribution of Phyllosoma larvæ of Palinurus, Pagurid Glaucothoz̈ larvæ, Crangonid larvæ, and Crab megalopæ, at the times shown, on June 17-18-19th, 1925. The plain, cross-hatched, black, and shaded rectangles represent "daylight," "dusk," "dark," and "dawn" respectively. The white spots and black circles indicate the average depths at which hauls were taken. 
numbers between 30 and $40 \mathrm{~m}$. at dusk (Fig. 4). In the dark they were almost evenly distributed from the surface downwards. At dawn they were still taken at all depths, but in very small numbers, and the majority were below $20 \mathrm{~m}$. In the daylight on June 18th the layers from the surface down to $10 \mathrm{~m}$. at any rate were practically vacated. On the following night the behaviour seems to have been much the same, except that the numbers caught were much smaller on all occasions.

Of other amphipods, Hyperiid sp. appeared almost only singly and in the deeper layers in the daytime, while in the dark on June 18-19th four were taken on the surface. Such truly bottom-living amphipods as Ampeliscus appeared also in the night hauls and at $27.5 \mathrm{~m}$. at dawn on June 19th.

\section{DECAPODA.}

\section{Pandalid LARVE.}

In daylight on June 17th most of these larvæ were taken at $30 \mathrm{~m}$. (Fig. 6). At dusk they were still most abundant about this depth, although a slight diminution is apparent in the layers above. By dark there has been a marked filling up of the layers above $25 \mathrm{~m}$., but the numbers actually at the surface are low. By dawn on June 18th the surface layers have been emptied and the majority of Pandalid larvæ were once more at $30 \mathrm{~m}$. A similar condition was apparent in the daylight on June 18th, but unfortunately owing to lack of observations from the deeper levels it is not possible to say whether, in reality, the majority were then below the depths sampled. By dusk on June 18th there is an apparent filling up of the layers up to between 10 and $15 \mathrm{~m}$., and in the dark there was a further extension upwards to the surface itself, though the majority were caught at about $15 \mathrm{~m}$. A downward movement exactly similar to that of the previous day was exhibited at dawn on June 19th, but there is a slight increase again in the daylight, possibly due to a swarm.

\section{Crangonid LaRva.}

Only very few Crangonid larvæ were taken in the daylight, and those only in the deeper layers (Fig. 5). There were, however, in the dark on both nights considerable numbers caught at all depths from the surface downwards, indicating a definite upward movement. At night the catches included many post-larvæ and a few early adult stages.

Phyllosoma larva of Palinurus vulgaris Latreille.

These larvæ appear to have been very near the bottom during the daylight on June 17th (Fig. 5). By dusk the majority had already 


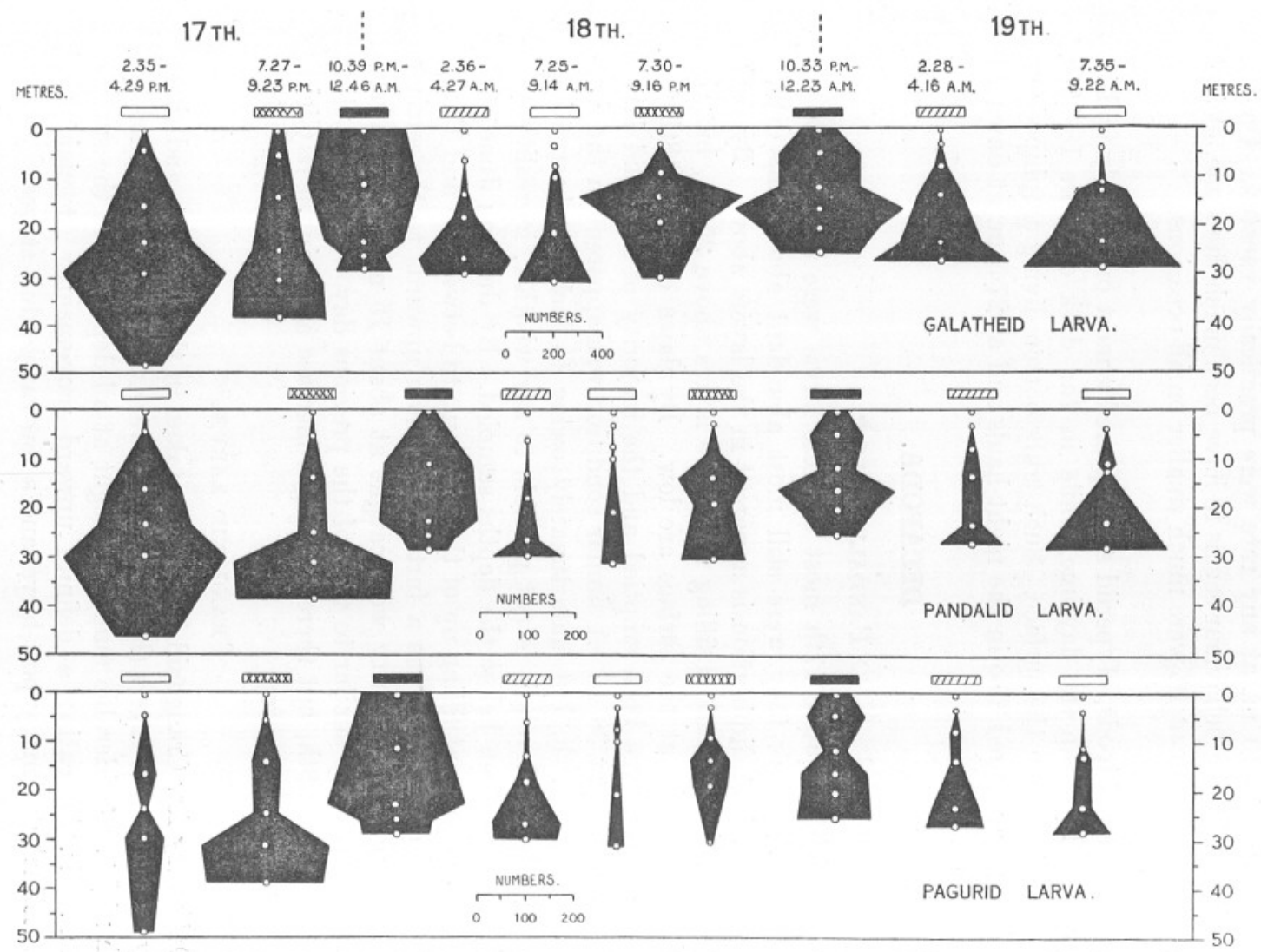

Fic. 6.- The vertical distribution of Galatheid larvæ, Pandalid larvæ, and Pagurid larvæ, at the times shown, on June 17-18-19th, 1925. The plain, cross-hatched, black, and shaded rectangles represent "daylight," "dusk," "dark," and "dawn" respectively. The white spots and black circles indicate the average depths at which hauls were taken. 
reached the layers between $15 \mathrm{~m}$. and the surface. In the dark the distribution was fairly even from the surface down to about $25 \mathrm{~m}$., but the numbers were somewhat less than at dusk, possibly owing to unevenness in horizontal distribution. By dawn there had been a very considerable reduction in numbers, and by daylight on June 18th they had almost completely vacated the layers down to $30 \mathrm{~m}$. A very similar behaviour was exhibited on the following night.

\section{Galatheid LaRVÆ.}

In daylight on June 17th the majority of these larvæ were taken at about $30 \mathrm{~m}$. (Fig. 6). At dusk they were still in this region, but by dark the upper layers were filled up to the surface itself. At dawn on June 18th the surface layers down to about $15 \mathrm{~m}$. had been vacated and the majority were taken at 25 to $30 \mathrm{~m}$. In the daylight there is an indication that a further downward movement had taken place, the majority being at $30 \mathrm{~m}$. and perhaps below this, though the deeper layers were not sampled. By dusk on June 18th there had evidently been a marked upward movement, most of the larvæ being captured at about $15 \mathrm{~m}$., but the surface layers down to between 5 and $10 \mathrm{~m}$. were still empty. In the dark the surface layers were filled up, but not so completely as on the night before, the majority being taken between 15 and $20 \mathrm{~m}$. A downward movement was again shown at dawn on June 19th, but there was little alteration in the daylight beyond a more complete emptying of the surface layers down to $10 \mathrm{~m}$.

\section{GaLatheid POST-LaRvæ.}

Although in the daylight on June 17th some of these post-larvæ were present high up in the water layers it seems most probable that the majority were really close to the bottom. There was on both nights a considerable increase in the numbers in all layers sampled up to the surface itself, followed by an emptying of the surface layers and a massing at depths between 20 and $30 \mathrm{~m}$. at dawn. (Amongst these may also have been included Porcellana spp. post-larvæ.)

\section{UPOGEBIA LARVA.}

On June 17th in daylight the majority of these larvæ were below a depth of $25 \mathrm{~m}$. (Fig. 7). By dusk they were extending their distribution up to between 10 and $15 \mathrm{~m}$., and in the dark they were most abundant actually at the surface. By dawn on June 18th they had left the upper layers and were mostly below $15 \mathrm{~m}$. In the daylight on June 18th they were apparently slightly higher in the water than at dawn, up to $10 \mathrm{~m}$. ; 
albeit the numbers were rather low, and it is perhaps possible that the majority lay below the depths sampled. By dusk on June 18th there was an evident increase in numbers up to a depth of between 10 and $15 \mathrm{~m}$., an increase which extended up to a depth of $5 \mathrm{~m}$. in the dark; but the surface itself was not fully populated as on the previous night. At dawn on June 19th the surface layers were emptied down to a depth of 5 to $10 \mathrm{~m}$., most of the larvæ being captured from about $15 \mathrm{~m}$. In the daylight there was an indication that the majority had moved down to $25 \mathrm{~m}$. and may be deeper.

The post-larvæ of this species were not taken in the daytime. They only occurred in very small numbers at night and at dawn, while one was caught deep down at dusk.

\section{Larva of Callianassa sp.}

The numbers of these larvæ in the collections were rather low, it being early in the season for them. In consequence the results are somewhat irregular, but there is a definite indication of upward movement at night.

\section{PAGURID LARVA.}

In the daylight on June 17th very few Pagurid larvæ were taken above a depth of $25 \mathrm{~m}$., and the numbers below this were also somewhat low, possibly indicating that the majority were very near the bottom (Fig. 6). By dusk there had been a large increase in numbers at 30 and $40 \mathrm{~m}$. In the dark the water layers from $30 \mathrm{~m}$. up to the actual surface were completely filled. By dawn on June 18th the larvæ had left the surface layers and most were caught at 25 to $30 \mathrm{~m}$., and in the daylight there is an indication that they may have been below $30 \mathrm{~m}$. At dusk on June 18th there was an increase at 15 to $20 \mathrm{~m}$., though the numbers are rather low, and in the dark an upward movement had filled the layers between the surface and $30 \mathrm{~m}$. A downward movement similar to that of the previous day was exhibited at dawn and in daylight on June 19th.

\section{GLaucothö̈ Larvæ of Pagurids.}

The behaviour of these bottom-living stages was very similar to that exhibited by the mysids. In the dark they moved up into the upper water layers as far as the surface itself, though the largest catches were still below $25 \mathrm{~m}$. (Fig. 5).

\section{Porcellana spp. zoez.}

The behaviour of Porcellana zoeae appears to have been extremely irregular. Lying mostly at $30 \mathrm{~m}$. in the daylight on June 17th, they were by dusk almost evenly distributed from the surface downwards 
(Fig. 7). At midnight there were enormous numbers at the surface. By dawn the layers down to $15 \mathrm{~m}$. had been vacated, but in the daylight on June 18th there appears to have been a slight upward movement. At dusk the distribution of Porcellana was much the same as in the daytime, but in the dark there was a large massing at $15 \mathrm{~m}$., the surface layers being almost empty. Dawn and daylight results on June 19th exhibit a progressive downward movement. The midnight behaviour on these two nights was apparently very uncoordinated, but may possibly have been upset by the presence of swarms.

\section{Crab zOE $\approx$.}

An examination of Fig. 7 shows that in the case of the crab zoeae (probably mostly Portunus spp.) there was a considerable increase in numbers in the layers above 15 to $20 \mathrm{~m}$. on both nights, an increase which was pronounced also at the surface itself. It is not quite obvious at what depth the majority were in the daytime. A study of the last five series (daylight, June 18th, to daylight, June 19th) seems to indicate definitely that in the daylight on June 18th the majority must have been below the depths sampled, because by dusk there was a considerable filling up of the layers up to a depth of between 10 and $15 \mathrm{~m}$., and this increase extends right to the surface in the dark. There was clearly a diminution in numbers at dawn on June 19th, with an almost complete emptying of the actual surface layers. In daylight on the 19th, while the upper layers have been depleted almost completely down to a depth of $10 \mathrm{~m}$., there is a great increase in numbers below this depth, possibly caused by a swarm. In the first five series the upward movement at dusk is not so marked; this is because in the daylight on June 17th the crab zoeae appear to have been almost equally abundant at all depths except at the actual surface. Whether this is a false impression due to the fact that the zoeae were extremely abundant at that time, and the majority lay even deeper than was sampled cannot be said.

\section{Crab megalope.}

In the daylight on June 17th the crab megalopæ appear to have been more or less evenly distributed from the surface downwards, but at dusk, while hardly any were taken above $20 \mathrm{~m}$., there seems to have been a very marked increase in numbers below $30 \mathrm{~m}$. (Fig. 5). In the dark they had migrated to the surface itself where they were caught in greatest numbers. At dawn on June 18th they seem to have retired once more to below $30 \mathrm{~m}$. In the daylight there was a slight upward movement, though there were fewer in the surface layers than on the previous day. At dusk very few were caught at all down to $30 \mathrm{~m}$., but there is again a 


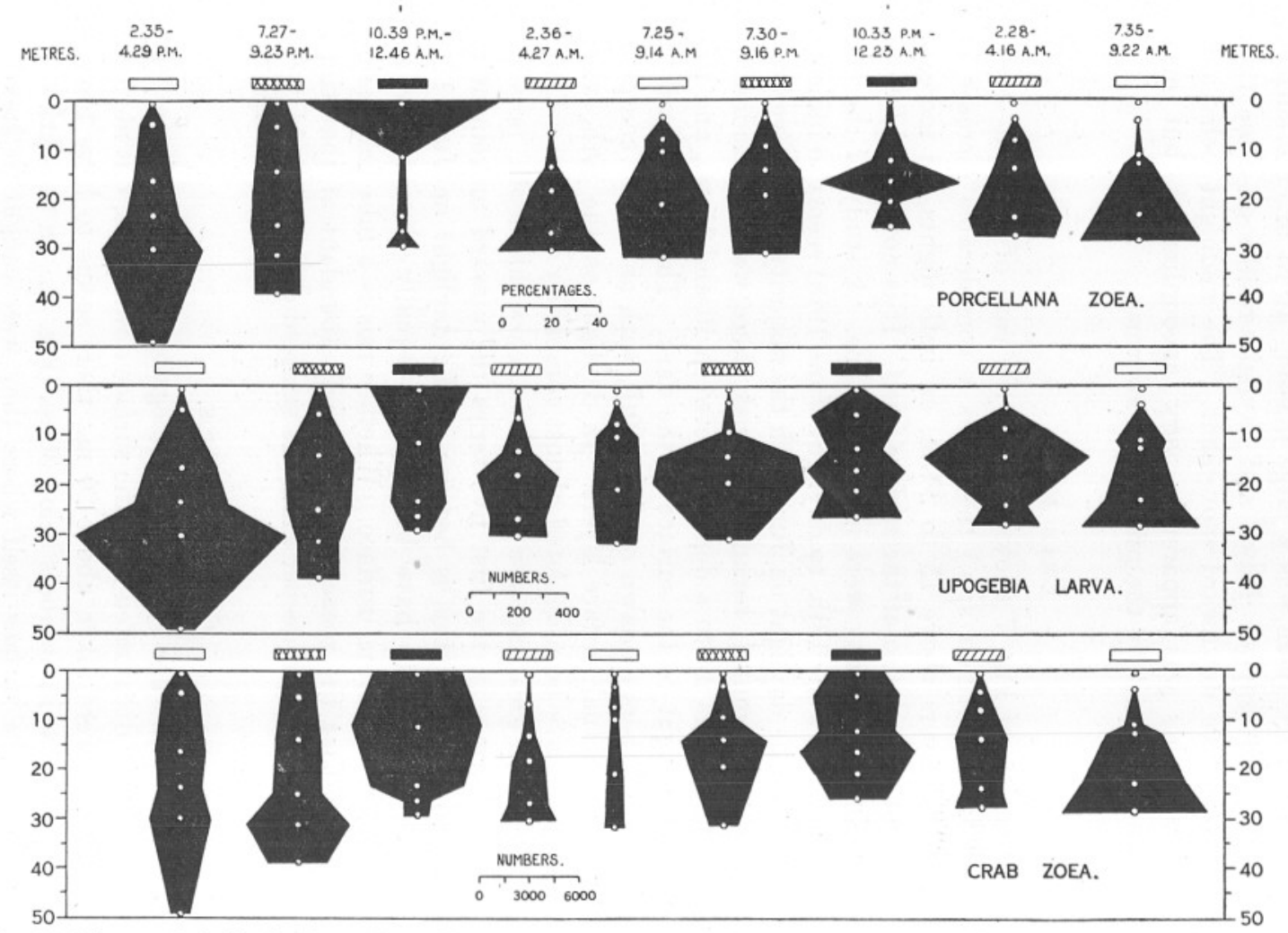

FIG. 7-The vertical distribution of Porceliana spp. zoeae, Upogebia sp. larvæ, and Crab zoeae, at the times shown, on June 17-18-19th, 1925. The plain, cross-hatched, black, and shaded rectangles represent "daylight," "dusk," "dark," and "dawn" respectively. The white spots and black circles indicate the average depths at which hauls were taken.

N.B.-Owing to the very large numbers, the diagram for Upogebia larvæ at daylight on June 17th is half the scale of the others. 
marked movement to the surface in the dark. At dawn on June 19th they had moved downwards to below $10 \mathrm{~m}$., and in daylight this downward movement has apparently continued.

Leander sp. larvæ, Alpheus larvæ, Pontophilus spinosus larvæ, Homarus vulgaris larvæ, and Axius larvæ were present only in very small numbers in the collections.

The presence of a few young Portunid crabs up to about $\frac{1}{4}$ inch in width was noticed at night at all depths.

Echinospira larvæ, Limacina retroversa, and Tornaria larvæ were only taken in small numbers. In the case of Echinospira and Tornaria larvæ there is, however, a slight indication of upward movement at night.

\section{REFERENCES.}

1. Russell, F. S. The Vertical Distribution of Marine Macroplankton. An Observation on Diurnal Changes. Journ. Mar. Biol. Assoc., N.S., Vol. XIII, No. 4, 1925, p. 769.

2. Russeld, F. S. III. Diurnal Observations on the Pelagic Young of Teleostean Fishes in the Plymouth Area. Ibid., Vol. XIV, No. 2, 1926 , p. 387.

3. Russelt, F. S. V. The Distribution of Animals Caught in the Ringtrawl in the Daytime in the Plymouth Area. Ibid., Vol. XIV, No. 3. 1927 , p. 557.

4. Russell, F. S. The Vertical Distribution of Plankton in the Sea. Biological Reviews, Vol. II, No. 3, 1927, p. 213.

5. Russell, F. S. A Net for Catching Plankton near the Bottom. Journ. Mar. Biol. Assoc., N.S., Vol. XV, No. 1, 1928, p. 105. 


\section{TABLE I.}

JUNE 17тH, 18тH, $19 \mathrm{TH}, 1925$.

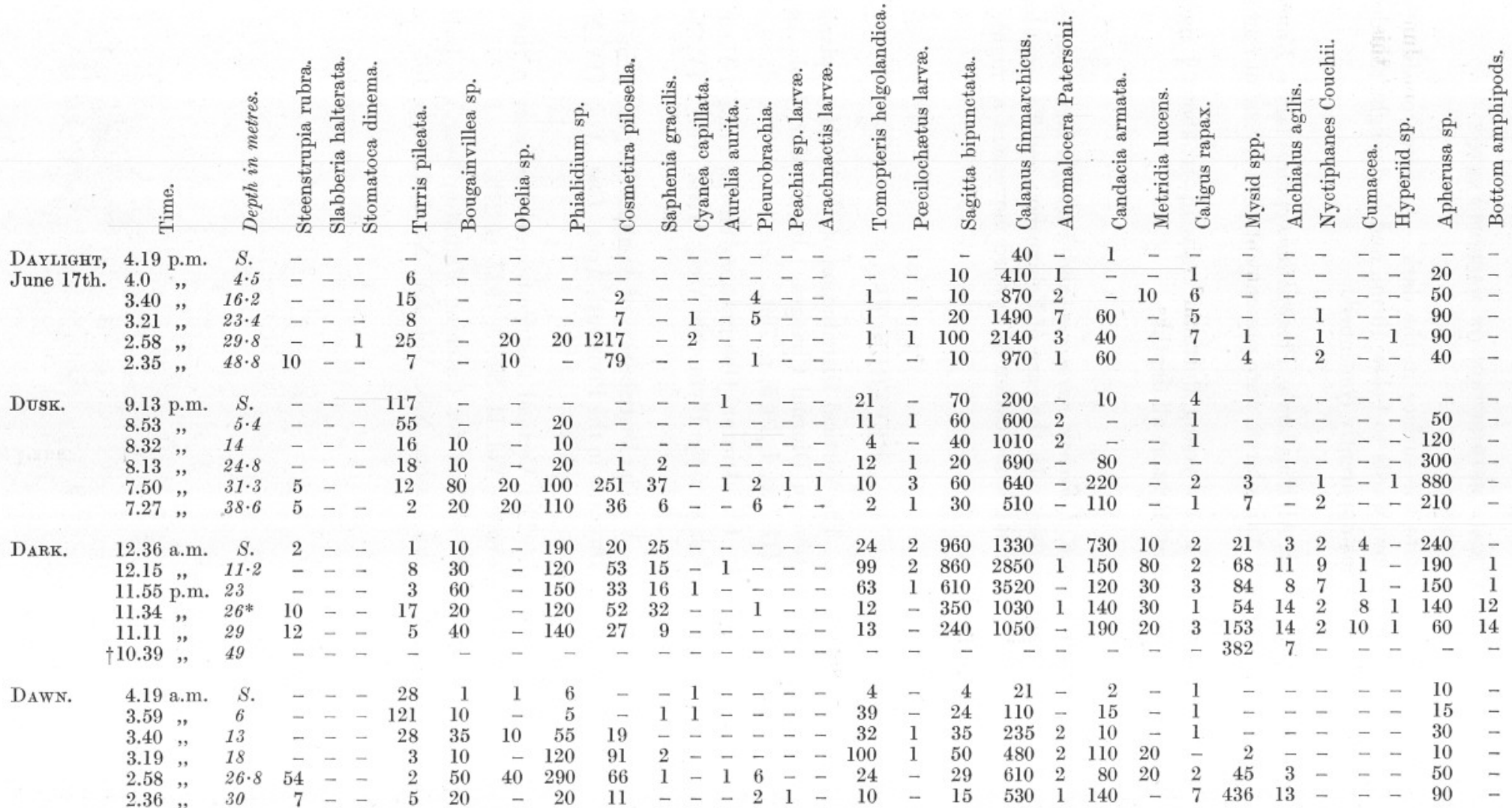


DAYLIGHT, 9.3 a.m. S. $\quad$ - -

June 18th. 8.45 , $\quad 3.2 \quad \ldots .5$

$\begin{array}{lll}8.27, & 7.5 & -\end{array}$

(7.8

$7.25, \quad 31.4 \quad 6=-$

DUSK.

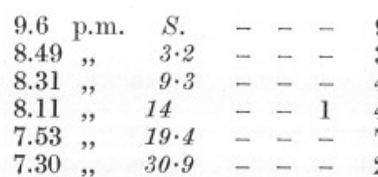

$1-\ldots--$

$\begin{array}{rrr}- & 17 \quad 175\end{array}$

$\begin{array}{llllll}2 & 7 & 620 & 1 & 15 & -\end{array}$

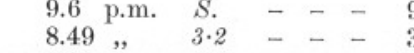

$\begin{array}{lllllllllllllll}177 & 22 & - & - & - & - & - & - & - & 3 & 1 & 65 & 44 & - & 1\end{array}$

$\begin{array}{lllllllllllllll}10 & 100 & 20 & 8 & 2 & - & - & - & - & - & 8 & - & 67 & 220 & 1 \\ 10 & & 10 & 3 & - & - & - & - & - & 6 & - & 64 & 330 & 2\end{array}$

$\begin{array}{lllll}10 & 40 & 10 & 36\end{array}$

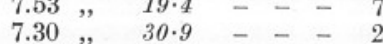

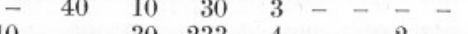

12.13 a.m. S. $\quad 1--$

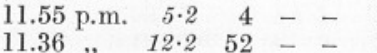

$\begin{array}{lllll}11.36 & , & 12 \cdot 2 & 52 & -\end{array}$

DARK.

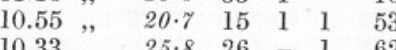

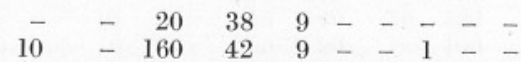

$\begin{array}{rrrrrrrrrrrrrrr}3 & 4 & 420 & 400 & \bar{r} & 210 & - & 2 & 3 & - & 2 & 1 & 4 & 100 & - \\ 49 & 1 & 820 & 1840 & 3 & 80 & 10 & 1 & 19 & 3 & 5 & 3 & 1 & 150 & 1\end{array}$

$\begin{array}{lllllll}85 & 1 & 670 & 1230 & 4 & 30 & -\end{array}$

. 25.826

$5704424-$
$-1504720-$

$61 \quad 3 \quad \begin{array}{llllllllrlrrrr}640 & 1810 & 2 & 80 & 10 & 3 & 40 & 11 & 8 & 1 & 1 & 80 & -\end{array}$

DAWN. $\quad 4.6$ a.m. S. $\quad$ - $\quad-134$

3.49
$3 . \mathrm{a}$.

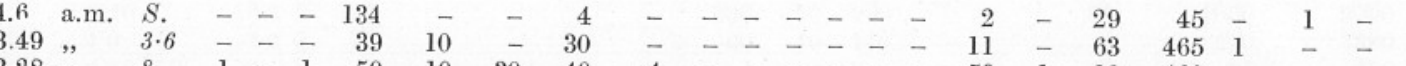

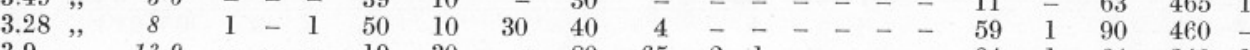

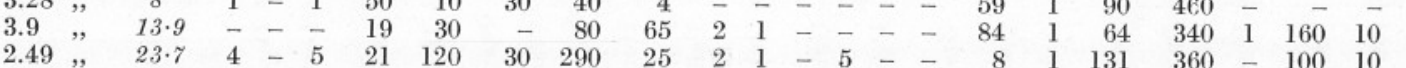

$2.28, " 27 \cdot 5 \quad 13-5$

DAYLIGHT, 9.12 a.m. $S . \quad-\quad-\quad 1$

June 19th. $8.54,, \quad 4 \quad-11 \cdot 1 \quad-\quad-4$

$8.35, \quad 11.1=12.7-58$

$\begin{array}{lllllll}7.56 & ” & 23.3 & \overline{9} & \overline{1} & \overline{2} & 63\end{array}$

$\begin{array}{rrr}120 & 30 & 290 \\ 10 & 120 & 40\end{array}$

7.35, $28 \cdot 5$

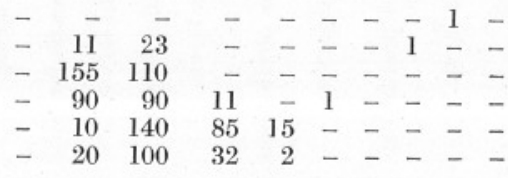

$13 \quad 12$

$1360-100-10 \quad 6$

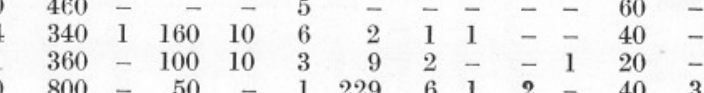

Maximum depth, $31 \mathrm{~m}$. : $26 \mathrm{~m}$. given as possible average.

$\begin{array}{rrrrrrrrrrrrr}5 & 12 & 9 & - & - & - & - & - & - & - & - & - & - \\ 32 & 314 & - & - & - & - & - & - & - & - & - & - & - \\ 57 & 1260 & - & - & - & - & - & - & 1 & - & - & - & - \\ 55 & 570 & - & 10 & - & 3 & - & - & - & - & - & 110 & - \\ 84 & 1410 & 4 & 20 & - & 6 & 1 & - & 2 & - & 2 & 270 & - \\ 79 & 1310 & 3 & 70 & - & 11 & - & - & 2 & - & - & 100 & -\end{array}$


TABLE I-continued.

JuNE $17 \mathrm{TH}, 18 \mathrm{TH}, 19 \mathrm{TH}, 1925$.

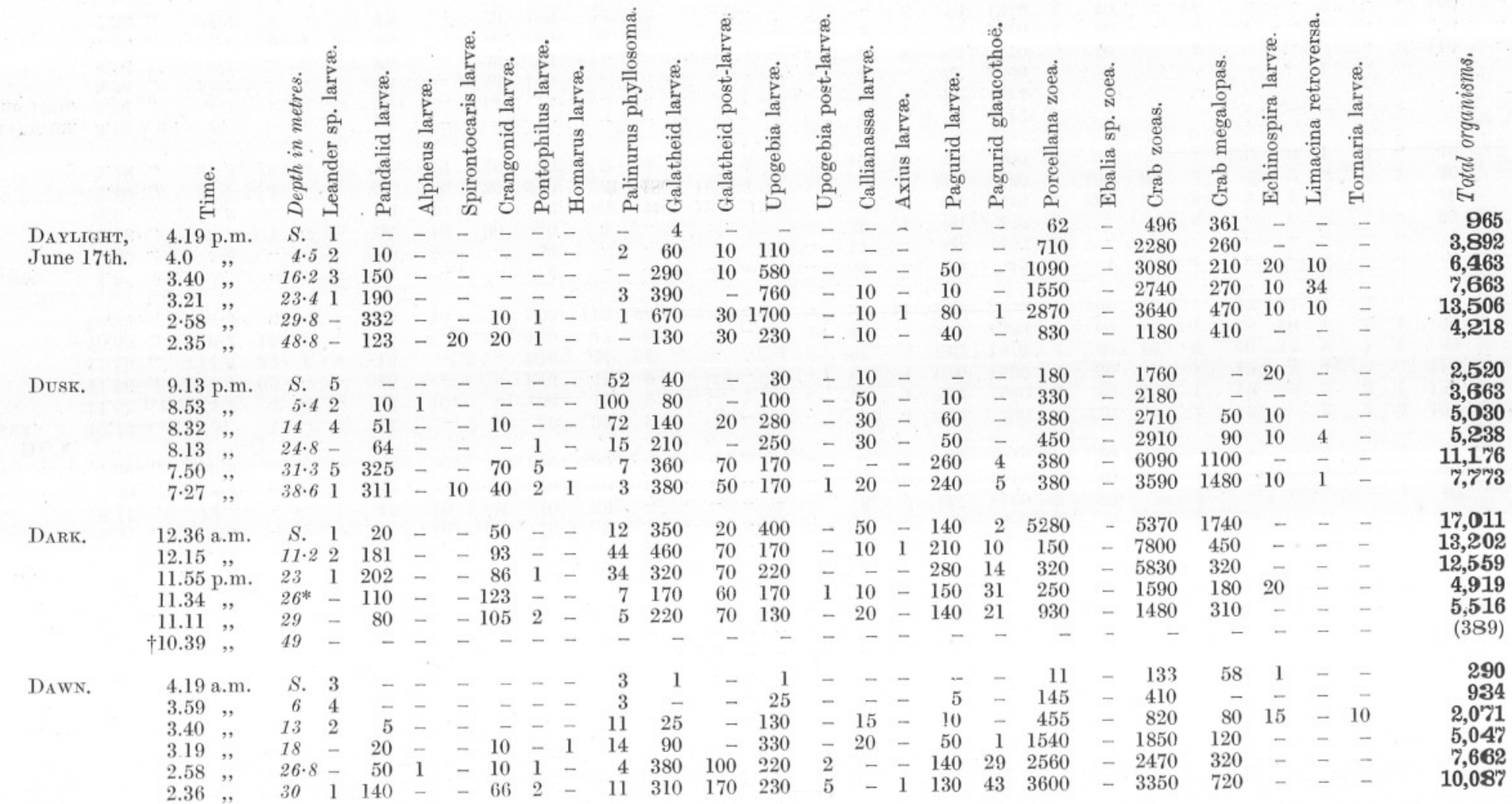


DAYLIGHT,

8.45 S.

8.45,
8.27,

8.6 ,

$\begin{array}{ll}3 \cdot 2 & 2 \\ 7 \cdot 5 & 4\end{array}$

$\begin{array}{rr}9.9 & 4 \\ 20 \cdot 8 & 4\end{array}$

$\begin{array}{lllll}5 & - & - & - & - \\ 30 & - & - & 5 & 1\end{array}$

4
4
40
90

$\begin{array}{rr}\overline{2} & 5 \\ - & 75 \\ - & 170 \\ 10 & 190\end{array}$

5
5
0
0

$-+$

-
10
5
20
35

5

47

15

7.25,

3it

$50-\quad-101-$

$3 \quad 305$

15165

$-10-20$
$-\quad 10-35$

$\begin{array}{r}410 \\ -\quad 405 \\ \hline\end{array}$

1030
$\quad 885$

$\begin{array}{r}317 \\ -\quad 390 \\ \hline\end{array}$

125

Dusk.

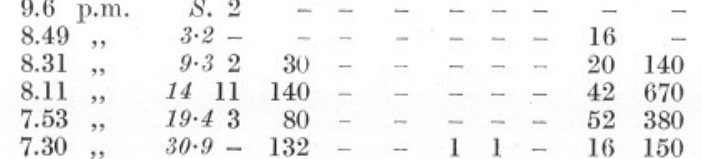

$-\quad 2$
$-\quad 15$
$-\quad 50$

$-\quad 2-$
$-\quad 15-$

$-6-33$

$51005--$

$30.9-132-11-16150-180-10-10-820-1750$

12.13 a.m. S. $\quad$ - $40-\quad-10-\quad-20 \quad 13040 \quad 40$

DARK.

$12.4110--201-$

$\begin{array}{llll}53 & 330 & 90 & 360\end{array}$

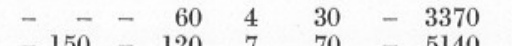

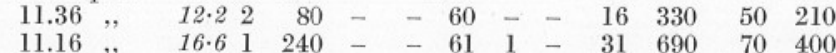

$\begin{array}{lllllllrllllll}11.16 & & 16.6 & 1 & 240 & - & - & 61 & 1 & - & 31 & 690 & 70 & 400 \\ 10.55 & , & 20.7 & 1 & 150 & - & - & 110 & 4 & - & 68 & 470 & 60 & 260\end{array}$

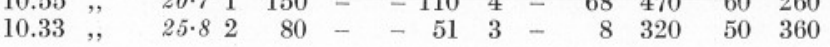

$190-50 \quad 9 \quad 310-4540$
1

S.

$-\quad-\quad-\quad-$

$390-140 \quad 10 \quad 160 \quad 30 \quad 5210$

$\begin{array}{lll}7 & 1 & -\end{array}$

472

1,106

2,516

8,021

7,828

4,344

DAWN.

$\begin{array}{llllllllllllllllllllll}4.6 & \text { a.m. } & S . & 3 & - & - & - & - & - & - & 1 & - & - & 3 & - & - & - & - & - & 10 & - & 51 \\ 3.49 & 3.6 & 4 & - & - & - & - & - & - & 4 & 10 & - & 22 & - & - & - & - & - & 80 & - & 755 \\ 3.28 & 8 & 2 & 20 & - & - & - & - & - & 13 & 50 & 20 & 330 & - & 30 & 2 & 20 & - & 480 & - & 1780\end{array}$

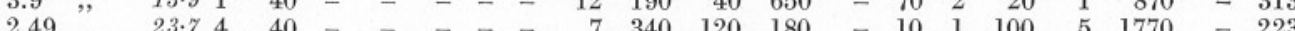

$2.49 " \quad 27.5-130--30--730-100-270$

$\begin{array}{rrrrrrrr}- & 10 & 1 & 100 & 5 & 1770 & - & 2230 \\ 6 & 10 & 4 & 120 & 20 & 1550 & - & 3070\end{array}$

$\begin{array}{ll}70 & 60-20 \\ -20 & -20\end{array}$

$80 \quad 40-10$

5,882
10,520

$\begin{array}{lll}630 & \overline{0} & - \\ - & -10\end{array}$

10,820

8,898
13,629

13,629

8,444
8,505

DAYLIGHT,

$7 \cdot 5-130-\quad-30-\quad 3480160270$

$\begin{array}{lllllll}10 & 4 & 120 & 20 & 1550 & - & 3070\end{array}$

$400-20$

(200 $40-10$

$500 \quad 20 \quad-$

June 19th.

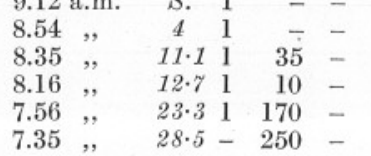

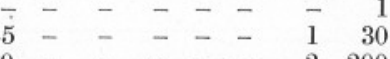

- $60 \overline{1}-2200$

$\begin{array}{ll}- & 1 \\ - & \\ - & 195 \\ - & 170 \\ 10 & 300\end{array}$

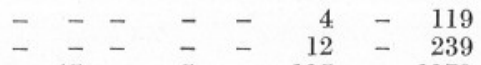

$\begin{array}{lll}1 & 1 & -\end{array}$

294
1,531

3,658

6,243

6,243

6,315

$7.35, \quad 28.5-250$

* Maximum depth, $31 \mathrm{~m}$. ; $26 \mathrm{~m}$. given as possible average.

+ Net struck bottom. 
